\title{
Re-Envisioning Female Power
}

\author{
Wildness as a Transformative Re-Source \\ in Contemporary Women's Spirituality
}

\section{Carine Plancke}

\begin{abstract}
Bricolage, the mixing of diverse religious resources, has been highlighted as a key process in contemporary spiritualities. Since, in this process, historically or culturally distant and foreign traditions are self-referentially drawn upon as representatives of a true spirituality deemed lost in the materialistic West, exoticism has further been identified as its core feature. In this article, through an in-depth ethnographic study, I examine operations of bricolage and exoticism in spiritual women workshops in North Western Europe that focused on the trope of the "wild woman." In particular, I highlight the transformational power of these retreats in reference to Michael Taussig's notion of mimesis as a sensuous embodiment of imagined otherness. I argue that, through enacting wildness in their bodies, the participants were overtaken by their own-historically determined-imaginations of primitiveness and naturalness, which not only created new visions of the feminine and female power, but also led to important life changes.
\end{abstract}

KEYWORDS: alterity, bricolage, Clarissa Pinkola Estes, exoticism, feminist spirituality, gender, Jungian archetype, mimesis, primitivism, Tantra, wild woman, Women Who Run with the Wolves

Nova Religio: The Journal of Alternative and Emergent Religions, Volume 23, Issue 3, pages 7-30. ISSN 1092-6690 (print), 1541-8480. (electronic). (C) 2020 by The Regents of the University of California. All rights reserved. Please direct all requests for permission to photocopy or reproduce article content through the University of California Press's Reprints and Permissions web page, https://www.ucpress.edu/journals/reprintspermissions. DOI: https://doi.org/10.1525/nr.2020.23.3.7. 
$\mathrm{M}$

ostly referred to as "New Age" in academic literature of the 1990s and early 2000s, contemporary alternative spiritualities ${ }^{1}$ are characterized by a lack of strong institutionalization and hence are generally considered "de-institutionalized" religion. ${ }^{2}$ They are promoted by multiple authorities who tend to relativize and undermine each other, ${ }^{3}$ leading to formations of varying depth and longevity. ${ }^{4}$ Numerous sources are drawn upon, and diverse traditions, styles, and ideas are combined into idiosyncratic packages according to spiritual seekers' perceived need for self-development. "Bricolage" is the term used to refer to this process of collecting and repackaging elements of older or culturally distant religious traditions, alongside diverse psychological and esoteric materials for individual consumption. ${ }^{5}$

In her study From Yoga to Kabbalah: Religious Exoticism and the Logics of Bricolage, Véronique Altglas ${ }^{6}$ reassesses the issue of bricolage as a main feature of contemporary spiritualities. Critical of the overriding emphasis on the processes of individualization and subjectivization in the making of modern religious life, Altglas shows that bricolage offers less freedom than typically assumed. Long-term historical processes and cultural encounters determine which foreign practices and beliefs are available to individuals. This use of available resources, the author shows, is self-referential. Only those elements are adopted that, after having been decontextualized from their cultural sources and reconfigured in psychological terms, lend themselves to be used as universal and flexible techniques for self-actualization. ${ }^{7}$ According to Altglas, religious exoticism is a key dynamic in this regard. The self-actualization desired by spiritual seekers entails a recovery of what they feel modernization has destroyed. The turn to non-Western religious traditions is explained by the need to recover a spirituality deemed lost in the materialistic West. This process is gender-related, ${ }^{8}$ in that women are typically the majority of those engaged in seeking their lost true nature through the use of culturally or historically distant religious resources, and generally, the process of bricolage relies on the view that mystic, intuitive, and spiritual dispositions are feminine.

This article deals with spiritual women's workshops in Western Europe (Belgium, the Netherlands, and the United Kingdom) centered on the trope of the "wild woman." These workshops demonstrate the abovementioned operations of bricolage and exoticism. The image of the wild woman was popularized in spiritual circles by Clarissa Pinkola Estes' bestseller Women Who Run with the Wolves: Contacting the Power of the Wild Woman, ${ }^{9}$ a collection of tales and myths from diverse traditions connected through the theme of the wild woman. Estes, a Jungian psychoanalyst, presents the wild woman as an eternal archetype present within each woman and found throughout times in different traditions, but repressed in our current society. The rediscovery of this archetype is believed to benefit the self-realization of contemporary women who, due 
to living in present-day society, have lost connection with their inner wildness. Estes clarifies that the notion of wild is not used "in its modern pejorative sense, meaning out of control, but in its original sense, which means to live a natural life." 10 Hence, it refers to the values of naturalness and authenticity, core ideas in contemporary spiritualities. It also refers to the "innate spiritual being at the center of feminine psychology" 11 and hence exemplifies connections that are celebrated in women's spirituality between the feminine and the power of intuition and mystical insight. ${ }^{12}$

The case study drawn from the workshops I observed strongly supports these ideas. Wildness was interpreted as following one's spontaneous impulses and expressing one's true self and therefore entailed a capacity to move beyond habitual patterns and internalized social norms. As in Estes' book, the workshops had a psychological orientation and therapeutic aims for self-healing and self-realization. Diverse spiritual practices based on culturally or historically distant traditions, especially Tantra but also shamanism and Neopagan goddess spirituality, were drawn upon and mixed, with the theme of the wild woman as the common element. Because of these features, the workshops allow for the study of the process of bricolage, in Altglas' sense of the term, as a selfreferential tool: the resources used came to fit the psycho-spiritual framework of self-actualization and were made to resonate with the image of the wild woman. The workshops also show the logic of exoticism. Participants were Western, nearly exclusively white, and mostly middle-class. The wildness they felt they had lost through their modern lives was claimed elsewhere by appropriating images and practices from generally non-white, non-Western, or premodern women. The latter were self-referentially used in opposition to and as a remedy for their modern, civilized, inauthentic, and hence damaged selves.

Exoticism, in Altglas' view, relies on the accentuation of the otherness of ideas, practices, and people. She distinguishes exoticism with regard to religious practices perceived as culturally other from a process of conversion to the religion these practices originate from. The latter necessarily entails the adoption of a new way of life and identity. ${ }^{13}$ The studied workshops definitely did not trigger conversions in this sense. There was not even a real encounter with cultural others, since the conveners were Europeans, drew their inspiration from other European workshop facilitators and offered practices they loosely presented as being inspired by other, "more spiritual" and "still authentic" traditions and peoples. Nevertheless, I intend to show in this article that an engagement with wildness as a property that is attributed to imagined others, but considered available for self-referential appropriation can induce life- and self-changing transformations. I am especially attentive to the gendered aspects of this transformation and the way the latter relies on a new way of envisioning female power. I also argue that, 
although starting from an exotic view of otherness, this transformation entails a diminishment of exoticism because, to a certain extent, the imagined alterity becomes incorporated and perceived as part of the self.

Furthermore, I aim to highlight the largely uncontrolled nature of this transformation, even if it is deliberately initiated and consciously used afterward as a means for reshaping one's gender identity. In order to do this, I draw upon the notion of mimesis as developed by Michael Taussig. ${ }^{14}$ Defined as the faculty to "yield into and become Other," 15 mimesis accounts for the transformative power that comes through the blurring between self and other; it relies on the observation that the representation may assume the character and the power of the represented. In other words, the made-up becomes real. ${ }^{16} \mathrm{I}$ argue that this is also what happened to the participants: they were overtaken by what they imagined. Wildness, which was represented as the uncontrollable and the never-to-be-planned, was felt to take over and act on itself. This allowed participants the possibility of actually having a lived experience of becoming the wild woman they have imagined. ${ }^{17}$ In this sense, constraints of availability of foreign beliefs and practices, and their framing within the new spiritual view of self-actualization, as pointed out by Altglas, are not the only reasons bricolage with exotic religious resources is less free than typically assumed. A lack of freedom, voiced by participants as the urge to follow "impulses," "inner knowing," or "the wisdom of the body," was actually experienced by participants due to the power exerted over them by the imagined wildness once it was embodied and enacted.

In his book Shamanism, Colonialism and the Wild Man, Taussig ${ }^{18}$ situates his discussion of mimesis in link with primitivism, particularly the Western projection of views of primitiveness and wildness on nonWestern peoples. He explains colonizers' cruel treatment of American Indians as an enactment of the savagery they themselves attributed to the Indians. ${ }^{19}$ Similarly, he claims that missionaries' need to seek shamanic healing and salvation from the civilization that tormented them resulted from a projection of their own idea of the power of the primitive, which is also a somatic projection of their own antiselves. ${ }^{20}$ Because of this history and the persistence of the "cult of the primitive," ${ }^{21}$ Taussig believes that present-day mimesis involves "the rehearsal of the practices of the body associated with primitivism." 22 This is evident in the workshops I will discuss; the views of the wild woman upon which these workshops rested pay tribute to a history of romanticizing non-Western women in terms of authentic mystical power. ${ }^{23}$ The aim of this article is to show precisely how participants in spiritual women's workshops deliberately enacted their own historically determined view of the primitive, as projected on the cultural other, and how, once they fully embodied it, they also unleashed its powers. From this perspective, the participants' sense of transformation and their perceived discovery of new aspects of themselves 
resulted from a confrontation with unacknowledged or rejected longings framed as lost authenticity and rendered accessible through their assimilation with an imagined primitive alterity.

\section{METHOD}

This study is part of an ongoing project on Tantric yoga workshops for women, ${ }^{24}$ for which I started ethnographic fieldwork in 2013. I have currently attended twenty-one three- to five-day workshops with different themes, six of which have focused on "the wild woman." Besides being a recurrent topic in Tantric workshops for women-as participants' accounts and an online searches have revealed to me-themes of "the wild woman," "the untameable woman," 25 "running with the wolves,"26 and "the she-wolf in each of us" are common in spiritual women's workshops in the countries involved in my research. Although breath work, body work, and visualizations are central to the Tantric workshops, other types of workshops foreground an engagement with female archetypes as revealed in goddesses or female heroines and/or the use of creative means such as writing, painting, and dance. Some of these workshops explicitly mention Estes' book as their main source of inspiration; others do not, but nevertheless reveal very similar views. The latter is the case for the workshops examined here.

In addition to ethnographic fieldwork, I also conducted in-depth interviews with workshop participants and conveners. The interviews took place at my own home or those of the interviewees and were semi-structured. The conveners were questioned about their background, their decision to become spiritual workshop leaders, their views with regard to their workshops, and their sources of inspiration while conducting workshops. Questions for the participants dealt with their motivation to sign up for the workshop, their previous engagement in spiritual practices, their experience of the retreat, and their views with regard to the eventual changes it brought in their lives. In order to delve deeper into their bodily experiences, I used Pierre Vermersch's explicitation interview technique. ${ }^{27}$ This included asking interviewees to single out an important moment in the workshop and, with prompting, to evoke it in full detail in order to provide an in-depth description of what was important at that moment.

For this article, I focus on a workshop in Belgium in which I participated three times between 2013 and 2015, and for which I conducted interviews with the two conveners and 18 participants. I describe the recurring features of the workshops; although they presented some variations from one year to the next, the general aim, method, and underlying views remained the same. I do not claim that this particular example is fully representative of this type of women's workshop; the 
workshops are variable, as they have no fixed template and are composed by conveners who develop their own practice without being supervised by some larger organization. However, this workshop shares important aspects with the other wild woman retreats I attended. In developing the theme of the wild woman, all of them drew not only on Tantra, but also on American Indian or Celtic shamanism and Neopagan goddess spirituality. They all were composed of the following elements: breath work, body work, dance, sound, nakedness, visualizations, expression of emotions, verbal sharing of one's experiences, use of a shamanic drum, presence in nature, engagement with the four elements, contact with the earth conceived of as a nurturing mother, and rituals focused on nature spirits and on a generic, immanent goddess who was said to be present in nature and in each woman. ${ }^{28}$

\section{CASE STUDY OF A WILD WOMAN WORKSHOP}

The workshop presented here as a case study is a three-day retreat that took place in summer on the property of an ecological community. The space was comprised of a main building and some acres of land with a mixture of permaculture gardens, wild vegetation, trees, and a small pool; it also housed some yurts and a caravan. Participants slept either in their own tents, in one of the yurts, or on the wooden floor of a space in the main building in which, for the occasion, a small altar had been erected with an Indian goddess statue, ${ }^{29}$ flowers, and goddess cards. The group consisted of two workshop conveners and around 10 participants, all women, with ages ranging between 25 and 65 , although most were between 35 and 45. The fee for the workshop was 240 euros in addition to accommodation and food costs (about 150 euros). The workshop conveners, An and Nathalie, were both active in the wellbeing counselling sector for individuals and groups. In organizing the workshop, they drew on a range of inspirations belonging to the broad field of contemporary spiritualities. Besides emotional body work, shamanism, and goddess spirituality, Tantra was the main source of inspiration. Both An and Nathalie had become acquainted with these practices through participating in other courses and gatherings, mainly in the Netherlands. However, they did not simply assemble copied exercises for their workshop. Instead, they gathered on a warm summer day in the garden of one of their homes and began embodying the wild woman, which they interpreted as letting their authentic selves and spontaneous impulses live. They then selected a few practices from this process and set up the program. ${ }^{30}$

On the first day of the workshop after everyone had arrived, a welcome ritual was held. We gathered barefoot in the garden within a circle of trees. After a moment of silence, attending to our breath and feeling 


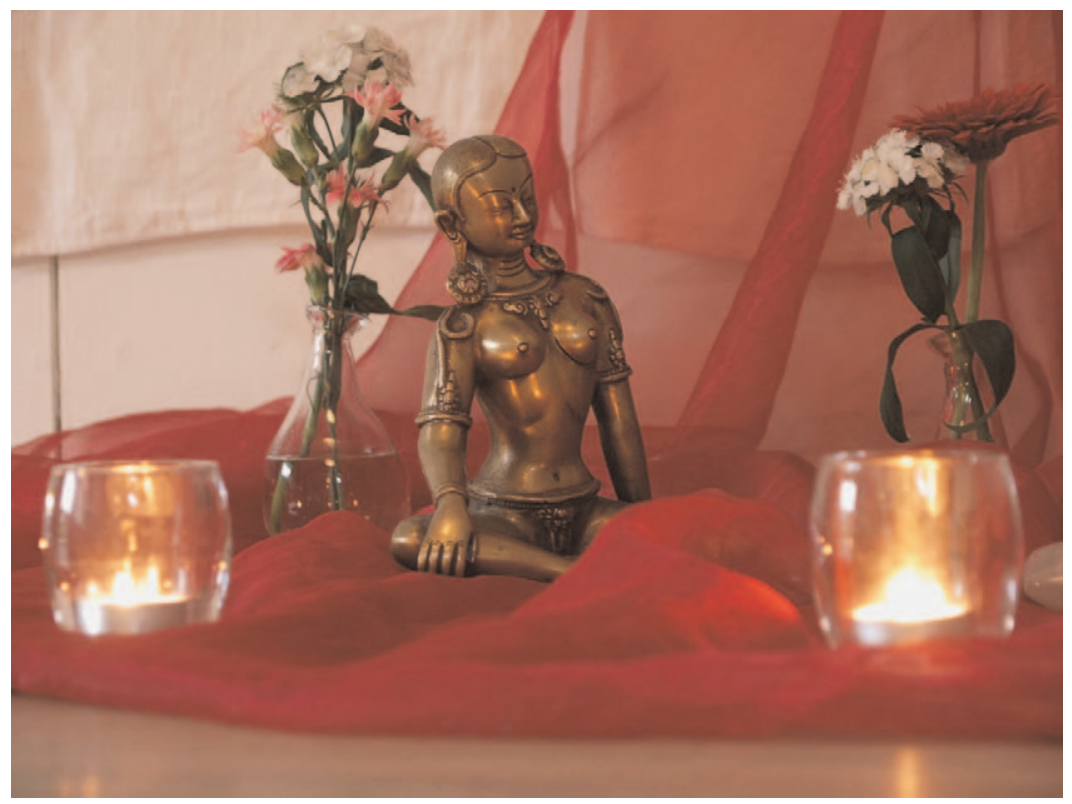

Goddess altar as set up during the studied wild woman workshops.

the earth, An started playing a shamanic drum and invoked the goddesses of the four elements — earth, water, fire, and air $^{31}$ —as well as the goddess that resides in each woman: Babayaga, the wild woman goddess. She then blessed the circle by igniting a piece of aromatic charcoal and waving it in a spiral in front of each woman with the words, "And for your wild woman." After this ritual opening, some free dancing and some words on how we felt, Nathalie invited us to share our answer to the question "Where do I withhold my wild woman?" with a partner, without giving comments or judgements. Following this activity, we were divided into three groups-water, earth, and fire ${ }^{32}$ - according to our own choice, and each group received tasks related to their chosen element.

The afternoon was devoted to the "kuṇ dalinī exercise,"33 accompanied by music from 5Rhythms ${ }^{34}$ founder Gabrielle Roth. One woman knelt on all fours, breathing continuously (i.e., without a break between inhalation and exhalation). When she felt the impulse, she started moving her hips and then her spine in an undulating way, making sounds as they arose, and gradually came to a standing position. All along, her partner in the exercise helped her by exerting pressure with the thumb, index and middle fingers on her sacrum. The aim of the exercise, as explained by An, was to "find a pure, authentic energy, a primitive power" and "connect again with our past when we still walked on all fours, before we were civilized and had all kinds of norms." This was followed by a creative exercise with clay prepared during the break by 
the earth and water women. The evening consisted of a goddess visualization in the yurt. While seated in a meditative pose or lying down, Nathalie invited us to visualize how we passed through a hole into a huge tree, descended through its roots into the earth, met our wild goddess, gave her a gift, received one in return, and went back to the surface of the earth through the roots of the tree. The day ended with a gathering around the fire built by the fire women.

The second day started with sound improvisations in the yurt. Subsequently, some grounding and tension-release exercises in a circle outside introduced the major exercise: the lioness salutation. ${ }^{35}$ The aim of this exercise was to get into the sensation of being a catlike animal, expressing it through movement and sound by following spontaneous impulses in the body. The exercise took place outside in the grass. We began in a circular configuration on all fours. We first spent some time exploring on our own, and then An invited us to begin interacting with each other according to the prevailing mood: affectionate, seductive, challenging, or assertive. After a small break, An and Nathalie playfully suggested there was a mud pool we might go in naked. Two of the times, this resulted in throwing mud and/or massaging each other with it; another year, in sacredly honoring our bodies: each woman went to the middle of the pool in turn, while the others blessed her body by stroking it with mud.

The afternoon was set up as a space for more personal exploration of the wild woman. After a sharing circle focused on how we were feeling, An asked us to write down our image of the wild woman and how we could concretely express it during the workshop. Ways of living the wild woman that I observed included body painting, nakedness, massage, dance, touch, playing in the mud, improvising with instruments, creating a ritual around a fire, and dressing up in unusual clothing, such as American Indian-style or tiger-motif garments. The day ended with another gathering around the fire prepared by the fire women, this time in a more ritualized way. Nathalie asked us to take a small stick and throw it in the fire while stating an intention to let go of something. The thing to be released was, for instance, one's self-image as "the nice girl" or negative, diminishing views of oneself.

The last day began with dancing to music we had brought, followed by a temple ritual for which we donned white clothes. The ritual was led by Nathalie and took place in the yurt or in a circle of trees decorated with orange, reddish, and pink veils. The Indian goddess statue was removed from the altar and placed in the middle of the space, and a previously prepared list of meditative, instrumental music from India played in the background. We gathered in threes and took a mat or mattress, decorating it with cloths we had brought. Two women took on the role of priestesses, serving as a channel for the goddess. First, they made a namaste —a bowing gesture with the palms of the hand pressed 
together in front of the chest- to each other and to the third woman. Then, they purified the latter woman who was lying down on the mattress by gently stroking her using a sponge and warm, perfumed water and circling her with incense. Then, by touch, words, or other gestures, they conveyed the quality the woman wished to receive from the goddess (as she has communicated to them beforehand). After a final namaste, the women switched roles. Afterward, we went silently into the surrounding nature. The afternoon ended inside the circle of trees with some dancing, a final sharing circle, and a last dance to the song "Totally Wild and Absolutely Free" by Miten and Deva Premal.

\section{A SHARED RE-IMAGINATION OF FEMALE POWER}

In their body- and practice-orientedness, the workshops aimed at giving the participants a feeling of what wildness is rather than transmitting a clearly defined view. The interviews nevertheless presented a strikingly similar imaginary around the figure of the wild woman that was disclosed in the way participants related their experiences of the workshop and the impact it had on their lives. The manifestation of a specifically female power, distinguished from male power, was one of the recurring aspects linked to the idea of the wild woman. It was present in the interview I had with Elke ${ }^{36}$ who, in telling her motivation to sign up for the workshop, expressed the need she felt to access a feminine power in a world dominated by men and the desire to get out of being stuck in achievement-oriented and rational thinking. She explained how the weekend taught her to follow her intuition rather than rational thoughts. This came about in an interaction with the goddess ${ }^{37}$ in a quite unexpected manner. Having ignored her longing to sleep in the yurt, reasoning that this was too "alternative" for her, she decided to sleep in the communal space and did not revise that decision, since she felt that once she had decided something she had to logically stick to it.

I slept right near the altar. I had the feeling-it is strange-but I dreamt that the goddess who was there on the altar kept me awake. I slept very bad and then I woke up and looked straight into that statue- "Ouou [expression of anger], I want to sleep!” And again.... That goddess symbolized the inner fight to let go of things [e.g., patterns, preconceived thoughts]... I also learned that being a woman is meaningful in itself. Before it was just: You are either a man or a woman, but you all have to do the same things. If you are pregnant, you should not complain. Giving birth should go as fast as possible so you can get to work again. All that kind of rationality.

Other interviews also touched on the importance of typically female body experiences, such as giving birth and menstruation, as ways of 
accessing a female power that is ignored or diminished in society's focus on self-determination and linear activity. Indra ${ }^{38}$ told me how she suddenly became aware of wanting to be a mother while she had always resolutely said she did not want any children. It was the improvisation exercise on imagining what a wild woman means that brought this "opening," as she called it:

What suddenly came to me was: a wild woman is someone who gives birth, is very wild, instinctive, but also very natural, very normal. I remembered a woman I met who gave birth squatting while holding on to a tree, a Spanish woman.

After the workshop, during an ayahuasca ceremony, she realized it was the unwanted pregnancy of her elder brother's teenage girlfriend and the strong repudiation by her family that prompted Indra's decision to never have children and preserve her autonomy. The realization of her wish to be a mother and her giving in to that wish further led to a reconfiguration of her practice as a therapist, which she saw now as maternal caring for her clients. For Antoinette, ${ }^{39}$ an intuitive but inhibited understanding of birth and death, as manifestations of female power and the cyclic nature of reality, also came up with strength during the workshop, especially during the lioness exercise. First, a traumatic memory came back of how she wanted to give birth on all fours but was prevented from following her intuition by the medical staff and felt she had been rendered powerless in that way. Later on, she started to mourn and felt a desire to go into the earth without knowing why. Only afterward did she make sense of it in terms of a prophetic intuition:

I ended up with death. That was very good, very powerful. I was also happy that that came in my path. I have a very positive attitude toward death. For me death is something that is part of things.... When I came back, I went to a friend because I was worried. She was ill and they did not know what it was and then, she just had received the news that she had pancreatic cancer, that she was terminally ill. I felt that that had preoccupied me.... Afterward, I thought: Why did I want to go in the earth? Why that mourning? Sometimes, I have a bit of Cassandra in me.

Menstruation was another topic that frequently emerged as an important aspect of woman's power different from male power, but unrecognized in society and repressed in the search for equality with men. Veerle, ${ }^{40}$ for instance, related her experience:

I really wanted to do things on my own, to manage my life on my own, that male power. Then I felt: surrender now for once, the flow of life leads you to ask an unemployment allowance.... I just want peace, just let me be for once, how does not matter anymore but stop fighting and proving yourself. In the weekend, there were many women who asserted, 
"My moontime [menstrual period], then I want to rest." I thought, "Yes!" That was great to hear.... There is also an inner man in every woman. She wants to prove that she can do it on her own. She also wants to do a full-time job, like a man. Periods do not count in this society.

Afterward, Veerle decided to participate in a supposed American Indian womb ritual in which the woman sits on the earth and lets blood drip into it during menstruation. She went to a camping site to do that, but once in the bush, heard a noise, and immediately, an old fear surfaced that a man was coming to rape her. This image revealed to her the imprint of socially determined gender views-in this case, the view of women as weak and in danger of attack by men-and showed how she had integrated the idea that going beyond habitual patterns-here disclosing nakedness in public areas-is dangerous. The importance of defying gendered norms in order to be able to honor the female body was also evident with regard to the mud and clay smearing. Several women told me how the image of naked women smeared with mud on the workshop website influenced their decision to sign up. Ine,${ }^{41}$ who was one of those particularly attracted by this aspect of the workshop, described its socially transgressive aspect with regard to norms on femininity in the following way:

That mud pool was way beyond, just way beyond the norms and limits and once you are there, it is gorgeous that you can go beyond it.... If you see how much joy and energy that gives and maybe a bit of anxiety, but yes. It is $\mathrm{OK}$, it is safe, here you can do it, you are beautiful... . It is learning to accept your whole body. Also seeing that other bodies, other women, are different and beautiful in their own way, have different forms, and dare to come to a touch. We did not learn that as girls, as women. To be nice, smartly dressed, but not naked and definitely not touching and smearing with mud.

The feeling of freedom when being able to go beyond certain social expectations that often weigh heavily on women-in this way accessing one's power-was also the main theme in my interview with Marleen. With two small children and a job as a nurse, Marleen ${ }^{42}$ had very little time that was not taken up by her family and professional duties of caring for others. She deliberately tried to maintain the very welcomed, but fleeting feeling of freedom she gained from the workshop through objects and images, recalling her experience of wildness:

I remember when we could dance to our favorite music. I remember also that, the whole time, I held my arms up in the air. I still know why very clearly. It had to do with the sternum, something that had to come free and I still remember how, the whole time, I held my arms up in the air... That song [the one she had brought to the workshop to dance upon the last day], when I had discovered it, it was so true. My 
interpretation is that it is about our being imprisoned in society, what they make of us, that we are so far from our nature.... After the workshop, I have made a kind of small altar in my room.... I also had discovered a small shop where I had found a card with a woman wearing a long dress in the forest, and she stands with her arms upward amidst the trees.... During a certain time, I went there to find peace in moments I needed it. Still now, if I look at that card, it still does that to me. Oh, it is so, so myself that I meet there. I remember. Once I needed something and I opened the cupboard and I saw it. Immediately it was again, voum! Oh, my card! No, if it ever would get really bad with me, and I saw that card, I am sure that immediately it will be better. It is the core of my being, what gets me going.

In this excerpt, Marleen brings what she describes as her true, deep self in link with an image of a kind of fairy-tale wood-woman. She experienced this image of wildness, which conjured up ideas of naturalness, as the deepest part of herself which she was in danger of losing through social pressure on expected feminine behaviour.

Throughout these interview excerpts, wildness and female power are interpreted in specific ways. In distinction from male power, wild female power has to do with intuition, visionary gifts, a capacity to let go and move with the flow, and an awareness of the cyclic nature of life as experienced in the rhythms of the female body. These views closely parallel the ones expressed by Estes' (1992) book on the wild woman. Estes also points to the negative impact of the vilification of women's body forms and the obsession with properness and rule-governed behavior on the wild self that, in her view, needs recognition and expression through play and creativity. These views are also foregrounded in the interview excerpts.

The participants in the workshop had been exposed to varying degrees to ideas circulating in new spiritual milieus. A few participants had never participated in similar workshops before, but had done some online research and had gathered knowledge through a variety of books. Most had been engaged in a diversity of spiritual practices, ranging from shamanism, 5Rhythms, ecstatic dance, reiki, yoga, Tantra, and Daoist practices, to diverse psychotherapeutic approaches or coaching and more female-centered practices such as Red Tent gatherings. ${ }^{43}$ The workshop conveners themselves had developed the workshop out of their own participation and training in a number of diverse spiritual and therapeutic practices, similar to those of the participants. The participation in a diverse but internally interconnected field of practices explains the integration of common views among teachers and participants. Furthermore, without being expressed in a dogmatic way, elements of this view were voiced in explaining the different exercises. For instance, it was constantly recalled that it is important to follow the wisdom of the body rather than the mind. The idea that there is a primitive, intuitive 
wisdom in the body was also explicitly expressed during the kundalini and lioness exercises. Moreover, the sharing sessions during the retreat also contributed to aligning the participants' views. Participants recognized themselves in what others shared and, hence, made sense of their own experience in similar ways. Or, when expressing what happened during the exercises, they used words reminiscent of those proposed by the conveners.

\section{BRICOLAGE AND THE MAGIC OF MIMESIS}

Estes refers to a diversity of traditions to underscore her views, using Eastern and Northern European, New Mexican, American Indian, African American, ancient Greek, and Asian tales and myths and integrating references to ancient goddess cults. In this sense, Estes realizes the bricolage typical for contemporary spiritualities, relying on universalist views and their reinterpretation through the idiom of selfactualization. A similar process happened in the workshops, in which the practices were inspired by a diversity of sources united around the common goal of giving space for the wild woman to exist. Both in the presentation of the workshop and during the actual workshop, the notion of the goddess who manifests both in nature and in each woman, who opens up to the natural flow of life, was frequently used. This evinces a connection with western goddess spirituality that harbors a similar view of the divine. ${ }^{44}$ According to Starhawk, an influential Wiccan thealogian, goddess spirituality "honors the wild and calls for service to the earth." 45 This entails in her view a deep questioning of society. Likewise, in the workshop, conveners saw wildness as letting go of habitual patterns and following one's spontaneous, natural impulses without being governed by norms on what should be done. The importance of reconnecting with the earth and the link drawn between the earth and the feminine further resonate with Neopagan goddess spirituality. ${ }^{46}$

Tantra is integrated in the workshop with reference to similar views of the feminine as sacred, the importance of spontaneity, and a link with nature. The specific influence that informs the conveners are the teachings of Daniel Odier (1945-present), a Swiss author and screenwriter who was given Tantric initiation by a yogini (female yogi) in Kashmir during his travels in India in the 1970s. ${ }^{47}$ After his return and several years of teaching at North American universities, Odier created the Tantra/Chan Centre in Paris, which existed from 1995 to 2000. The "Centrum voor Tantra" in the Netherlands, where both conveners have done most of their training, follows Odier's teachings. Odier has contributed to presenting Tantra in the West as a path that can serve women's liberation because it does not consider women to be inferior, unlike most religious traditions. ${ }^{48}$ In his books, he highlights a reverence 
for women and the feminine, as taught in Tantra and Kashmir Shaivism. Besides the veneration of the "grand Goddess," he points to the existence of female gurus ${ }^{49}$ and the perception of the Tantric path as a feminine path because of the valuing of receptivity, openness, and love. ${ }^{50}$ In Odier's view, Tantra is also a path of spontaneity. Rather than discipline, Tantra teaches to follow the body and how it naturally guides spontaneity. ${ }^{51}$ Moreover, contact with nature was an important part of Odier's Tantric initiation. His first teachings consisted of forming contact with the five basic elements. ${ }^{52}$ Without presenting it as a kind of teaching, the workshop conveners rely heavily on the Tantric reverence for the feminine, its value of spontaneity and naturalness, and the importance of the natural elements. This allows them to make a connection with shamanism. The introductory ritual explicitly evokes shamanism by the use of the drum. By mixing it with western goddess spirituality, in invoking the goddesses of the four elements ${ }^{53}$, and further introducing a reference to Babayaga, a Slavic mythical figure who appears in one of the tales in Estes' book, it features one of the most explicit instances of bricolage in the workshop.

The participants themselves also realized this creative process of bricolage; they used different images or invoked varying entities or persons according to what they felt drawn to. For Elke, the goddess played an important role; Antoinette referred to an ancient Greek prophetess; for Indra, a Spanish-but somehow mythical-woman who gave birth on her own popped up; and Marleen was struck by the image of a fairy-like forest woman. These figures were invoked in the interviews with regard to experiences that were unknown, new, or remarkable for the participants. Here, bricolage with different resources was a way to access or to account for the access to a part of oneself that was usually not experienced and that induced distancing from habitually held views or ways of doing. The fact that the images referred, to different degrees, to cultural alterity manifests the process of exoticization as the shaping of an opposition between Western woman caught in the trap of civilization and another, non-Western "wild" woman who is more authentic and representative of true feminine wisdom. Yet, the attempt to embody this other and the experience that the other is part of oneself and even the very core of one's being blurs the logic of a neat opposition between self and other that exoticization entails. The other no longer remained an image of the repressed, denied, or longed-for aspects of one's self that one embodied for a while, only to come back to the old self, but rather became part of one's being. This reveals a more complex process of identity formation and transformation for which Taussig's concept of mimesis is helpful.

According to Taussig, mimesis as a dialectic between self and other is necessary to the very process of identity construction. He defines it as an "active yielding of the perceiver into the perceived so that the self is 
moved by the representation into the represented." 54 The expression of "active yielding" suggests that mimesis is a process that is neither completely mastered nor completely undergone; it is "a strange mixture of activity and passivity." ${ }^{55}$ Even when deliberately initiated, it has a power that takes over. This is possible because, besides imitation, mimesis involves "a palpable, sensuous, connection between the very body of the perceiver and the perceived." 56 This embodied dimension explains why mimesis has magical power in such a way "that we are thereby lifted out of ourselves into those images." ${ }^{57}$ Images here are not just visual, but include sound, smell, and movement, as well as feelings and atmospheres. ${ }^{58}$ In the workshops, this bodily dimension was strikingly present. The exercises entailed the adoption of specific body postures and a sensuous enactment in movement of impulses elicited through the images of the ancient temple priestess, the lioness and especially the wild woman. Here, mimesis was a rehearsal of body practices associated with primitivism and historically shaped imaginations of an original, authentic, natural, free way of being linked to a female power seen as mystical. The alterity endorsed in bodily enactment was projected onto non-Western or pre-modern others who were placed in opposition to the modern West and considered able to give back what civilization had taken away. Because of the mimetic faculty of "taking us bodily into alterity," 59 this rehearsal of an imagined pre-modern primitiveness did not leave the women unchanged. As the interview excerpts show, aspects of the participants' identity as modern Western women were questioned in a sometimes unexpected and disturbing manner that necessitated changes in lifestyle and self-perception. This entailed a distancing from the position of autonomous, self-bound characteristic of modernity, as well as from gendered norms limiting female power as distinguished from male power in its links to intuition, cyclical wisdom, and receptivity.

For Elke, the goddess appeared in her dream in a very unexpected way; it became active, no longer a mere symbol of intuition and female power she wanted to embody by taking part in the workshop. In the interview, she explained to me how during the final temple ritual, she felt that she was a medium for the goddess, which was a radically new experience for her. She felt this otherness powerfully moving through her during the ritual, representing the intuition she refused to follow until then. This experience had a strong impact on her life. She felt compelled to move away from an exclusively rational way of thinking and to regularly go to the woods to find a similar sensation of belonging to a larger whole. This allowed her in a next workshop to more easily follow her intuition without perceiving it as strange. She even decided a few months after the workshop to quit her job, which had entailed helping non-Western single mothers become self-sufficient. She mainly objected to the ideology of autonomy and self-sufficiency based on a logical management of one's life that was imposed on these women and that, 
according to her, went against their cultural background, which was mostly sub-Saharan African or Maghreb.

A similar transformative experience was related by Indra. She no longer excluded motherhood, previously felt as endangering women's autonomy, and reinterpreted her job in terms of maternal caring. The image of a strong natural birthing woman which, during the workshop, was unexpected and remote for her, gradually became an aspect of herself. The very sensation of strangeness at the appearance of this image, she first tried to wave aside as unimportant, since it clashed with her long-made decision not to become a mother, ebbs away since it became part of her. This case also shows that the image of wilderness does not necessarily have to be linked to a foreign culture. The birthing woman was Spanish and hence culturally close to Indra, who was of Mexican origin. The picture of women clad in mud on the workshop website is also a case of culturally-close women. These women are participants from a previous workshop and thus very similar to the prospective participant looking at them. It is the way of acting and appearing within a specific environment that is representative of wildness and becomes an exotic object of mimesis and not the identity of the women as such. This can equally cause or strengthen transformation. It clearly was the case for Ine, who emphasized the clash with habitual norms imposed on women emphasizing being nice and clean and prohibiting sensuous touch among women. Having already participated in workshops with similar exercises and having lived for several years in a yurt with little comfort and basic hygiene, Ine had already distanced herself from her child socialization into the ideal girl, but the fact that she still experienced a clash shows that the workshop reactivated this transformation.

Images not only induced certain experiences, but were also used afterward in order to give sense to experiences that were new and defy socially acceptable reality or previously held views or decisions. The alterity of the image reflects here a part of oneself that still feels alien with regard to one's ordinary being and social identity. For Antoinette, the identification with Cassandra allowed for the valuing and integration of an understanding of the death-life cycle and prophetic visionary powers that came to her unknowingly and felt strange, I assume, because this did not conform to prevailing scientific discourses. With this identification, Antoinette's self-understanding was transformed. For Marleen, the card was a potent reminder of the state of freedom she accessed during the workshop and had difficulties in maintaining when faced with social pressures she experienced as a wife and mother in giving and caring for others. Clearly, it was not an exotic image used just for a moment to then get easily back in the old self as before, reinforced in the opposition to the other. Rather, it was an image that she continually longed to realize as a deeper truth of herself, which was 
both her and alien to her, since often it was not accessed. While initially she was struck by the image on the card as a visual reminder of her experience during the retreat, she deliberately went back to it afterward in order to induce a similar kind of experience and feeling of freedom when she felt she had lost it.

The active, deliberately chosen embodiment of one's image of the wild woman in order to "get in touch with one's true self" was the explicit object of the improvisation exercise during the workshop. The power of mimesis to effect change was literally searched for but, nevertheless, also entailed a willingness to surrender into what happened when fully enacting one's imagination of wildness and primitiveness as the other part of oneself. This was particularly well explained in my interview with Ine, ${ }^{60}$ who for the improvisation exercise dressed up as a American Indian woman with a long, voluminous white skirt, amulets around her neck, and feathers in her hair:

At that moment, I feel something like "Wow." A voice manifests in me, a woman who is in me and wants to come out. My wise woman, a part of authentic Ine whom I love and who is very supportive and nourishing. ... If you feel resistance, you could say: How stupid is this, playing some role? ... I am glad I can go through that resistance and that the clothes are part of that role in order to manifest it and let it be. Why, then, that skirt and those amulets? Probably they are images I have picked up somewhere. I also always then see age-old fertility statues. ${ }^{61}$. . At a midwifery conference, I met a American Indian midwife who still had her roots and community there, who talked about a man who always carried a little bag around his neck with small pieces of the placenta of his grandchildren... I have also read the book of Ayla ${ }^{62}$ about how people lived in tribes a very long time ago. At certain moments of their lives, when they experienced something special, they had to put something in a small bag they carried, for instance red earth.... That feather is also special. Always when I go walking and find a feather, I put it in my hair. Or a flower. Then I am a bit different than usual. It opens a bit like, "Come on, Ine, be happy and let it come open." That is a very fine energy, but so hard to live in our society here. You are so quickly drawn into the hustle and bustle, all those things that have to happen, that have to be arranged. I hate that so much and I so easily get into that. At certain moments, if you put a feather in your hair, it is different.

This interview reveals with particular clarity the logic of bricolage in its mixing of references to American Indians and prehistoric peoples, as well the guiding idea that supported this mixture-namely, that of the wild woman as opposed to the modern, Western woman. Furthermore, however, it once more shows a movement beyond mere exoticism and a sought-after transformation of self. Ine was quite habituated in participating in these kinds of workshops; she ran her own women's circle, for which she often drew on American Indian traditions. However, her 
mimesis or embodiment of this image was not a temporary moment of escape leading to a short-lived fantasy of expressing the repressed part of herself. Ine insisted it was not just role-playing, but instead a strategy she pursued with regularity in order to effectuate a change in herself that she would have liked to have as a lasting feature of a new identity. As with the other participants, her aim was to let the imagined and sought-for otherness become part of herself, blurring the very distinction between "me" and "other."

\section{CONCLUSION}

The use of non-Western objects, images, and practices by Western spiritual seekers has been discussed predominantly as a form of neocolonialism that simultaneously romanticizes the non-West and remains in a racial logic of othering and assumes an unquestioned right to ownership. With regard to a certain fascination for Eastern spirituality, continuity with colonial politics has been pointed out in reference to Edward Said's notion of Orientalism. Whereas colonizers in the past mainly exploited the economic wealth of colonized people, individuals with private interests now appropriate the East's spiritual fortunes. ${ }^{63}$ Tantra is a particularly desired object amidst the East's attributes, which has been both vilified and romanticized in the Orientalist imagination and is now largely commodified. ${ }^{64}$ The use of American Indian traditional practices has been criticized even more harshly as a form of cultural appropriation, ${ }^{65}$ religious imperialism, ${ }^{66}$ or cannibalism. ${ }^{67}$ Prominent American Indian leaders and activists have reacted negatively to what they see as the misuse and exploitation of their spirituality by non-Natives, especially when the latter claim authority and enjoy commercial success through selling American Indian spirituality and knowledge in the form of books and workshops. ${ }^{68}$ This is said to not only mask, but also perpetuate the social oppression of real American Indian peoples. ${ }^{69}$

In addition to being considered an irresponsible act of cultural theft, women's attraction to consuming resources from other cultures has been attacked on the grounds that it rests on "skewed interpretations of feminism" that are stripped of their political dimension and conceived in the narcissistic terms of psychological individuation. ${ }^{70}$ Estes is one of the authors targeted by these critiques and accused of "cognitive imperialism."71 In a recent reassessment of the question, however, Crowley argues that the acts of appropriation by white women are not simply theft, as they also involve affection, incarnation, and reattribution. ${ }^{72}$ Since white women simultaneously obtain gendered satisfaction from these spiritual appropriations in the sense that they use them to transform their gendered identity, it is more fruitful in her view to 
understand than to simply reject them. This is the stance that has been taken in this article as well. More specifically, I have shown how the notion of wildness, in its association with authenticity and primitiveness, is used as a resource for transforming oneself and one's gendered identity. In reference to Altglas, it was shown that bricolage with a diversity of sources, while clearly being self-referential and reinforcing a romanticized view on the non-West and the pre-modern, also moves beyond exoticism. When fully embodying images of primitive alterity, the neat division between self and other becomes blurred. This upsets the logic of exoticism, especially when it leads to life-changing transformations in which what was once seen as other is now felt to be a core part of the self. Taussig's notion of mimesis ${ }^{73}$ defined as the faculty to "yield into and become Other" has proven highly useful to account for the transformative aspect of the embodiment of alterity. It allowed the bodily, sentient dimension of the process to be highlighted whereby the made-up somehow comes to be felt as real, shifting agency away from the mimeticizing person, who feels the imagined power of the primitive acting upon her.

The originality of Taussig's work not only consists of blurring the clear line between reality and construction, but also confronts the unquestioned attribution of power, control, and agency to the Western colonizer on the one hand, and of powerlessness and passivity to the colonized non-West, on the other. In simultaneously brutalizing and mystifying American Indians, the colonizers were trapped in their own imaginations of savagery and untouched purity. As for the colonized, in imitating the colonizers, they were not merely passively assimilating a Western model, but sought to appropriate the colonizers' power and herein reaffirm their own being. This article, in applying the notion of mimesis to the contemporary rehearsal of primitiveness by Western spiritual seekers, ${ }^{74}$ further questions the self-evident attribution of power to the West. While bricolage and cultural appropriation are usually seen as privileges of dominant white people who, in their positions of power, reproduce self-referential views of the other for their own benefit, this article shows that these participants are also overtaken by their own imaginations and projections regarding the power of the primitive. Conversely, and in the same logic of questioning the self-evident attributions of power with regard to gender, participants' agency as women has been stressed beyond the usual association of femininity with powerlessness. This article has shown how, via the transformations that happen to them, women recreate their gender identity in line with views on authentic female power.

The question of whether this is truly empowering for women has not been discussed. Nor have I addressed the presumed essentialism of gender views in women's spirituality. ${ }^{75}$ For these issues, however, I concur with a recent study by Chia Longman ${ }^{76}$ on women's circles in Belgium, the Netherlands, and Germany. The author maintains that the 
concept of femininity used in these circles does not fall into biological essentialist paradigms and is deployed as a ground for personal empowerment. While the discourse on the return to the female body might sound essentializing, the trope of female embodiment is used, in Longman's view, in an often abstract and open sense at the experiential, ritual, and symbolic levels. ${ }^{77}$ She further maintains that agency, rather than being caught in a resistance/compliance binary, emerges in this context through a re-valuation of femininity that involves an explorative, imaginative, and experiential process with regard to gender identity, which can be both affirmative or oppositional vis-à-vis traditional gender norms. ${ }^{78}$ The foregrounding of the imagination and the exploration of new possibilities are also what predominated in the workshops I have examined. In opposing the primitive to the modern, seen as the regulatory and the normative, the image of the wild woman was used as an incentive for a movement beyond the already known: an "opening," and a consequent curiosity about what might reveal itself within this opening.

I would like to thank Chia Longman, director of the Centre for Research on Culture and Gender at Ghent University, for her willingness to supervise and support this project. Furthermore, I am thankful to the workshop participants and conveners for sharing their views and experiences with me. This work was supported by the Flanders Research Foundation (FWO), under Grant number FWOOPR2017000501.

\section{ENDNOTES}

${ }^{1}$ Following Anna Fedele and Kim Knibbe, I use the term "contemporary spiritualities" rather than "New Age" since practitioners distance themselves from the latter while they generally identify with the term "spiritual." See A. Fedele and K. Knibbe, "Introduction," in Gender and Power in Contemporary Spirituality, edited by A. Fedele \& K. Knibbe, pp. 1-27 (New York, London: Routledge, 2013), 8.

${ }^{2}$ Steven J. Sutcliffe and Ingvild S. Gilhus, "Introduction: 'All mixed up'Thinking About Religion in Relation to New Age Spiritualities," in New Age Spirituality: Rethinking Religion, eds. Steven J. Sutcliffe and Ingvild S. Gilhus, pp. 1-16 (Durham: Acumen, 2013), 9.

3 Matthew Wood, Possession, Power and the New Age: Ambiguities of Authority in NeoLiberal Societies (Aldershot, Burlington: Ashgate, 2007).

${ }^{4}$ Steven J. Sutcliffe and Ingvild S. Gilhus, "Introduction," New Age Spirituality, 9.

${ }^{5}$ Stef Aupers and Dick Houtman, "Beyond the Spiritual Supermarket: The Social and Public Significance of New Age Spirituality," in Sutcliffe and Gilhus, 174.

${ }^{6}$ Véronique Altglas, From Yoga to Kabbalah: Religious Exoticism and the Logics of Bricolage (Oxford: Oxford University Press, 2014). 
7 The term "self-actualization" was coined by psychologist Abraham Maslow and became a key concept in the Human Potential Movement, which was closely related to the New Age movement. Maslow defines self-actualization to be "the person's desire for self-fulfilment, namely the tendency for him to become actualized in what he is potentially." Maslow, A., "A Theory of Human Motivation," Psychological Review, 50 no. 4 (1943): 382-383.

8 Altglas, From Yoga to Kabbalah, 262.

9 Clarissa Pinkola Estes, Women Who Run with the Wolves: Contacting the Power of the Wild Woman [London, Sydney, Auckland: Rider, 2008 (1992)].

${ }^{10}$ Estes, Women Who Run with the Wolves, 6.

11 Estes, Women Who Run with the Wolves, 9.

12 Cynthia Eller, Living in the Lap of the Goddess: The Feminist Spirituality Movement in America (New York: Crossroad, 1993), 84, $135 \mathrm{ff}$.

13 Altglas, From Yoga to Kabbalah, 11.

14 Michael Taussig, Mimesis and Alterity: A Particular History of the Senses (New York: Routledge, 1993).

15 Taussig, Mimesis and Alterity, xiv.

16 Taussig, Mimesis and Alterity, xvii, 86. With this view, Taussig goes against what he sees as the "suffocating hold of 'constructionism"” and "the passive view of nature it upholds." See Taussig, Mimesis and Alterity, xix. In a similar reasoning, Bruno Latour shows that the opposition between realism and constructivism is not more than a theoretical stronghold of modernity. In practice, "what we make, overtakes us." See Bruno Latour, Petite réflexion sur le culte moderne des dieux faitiches (Paris: Synthélabo, 1996), 46, my translation.

17 This goes with experiences that can be defined as "re-enchantment," see Carine Plancke, "Engendering Liminality: The Experience of Re-Enchantment in Wild Woman Workshops," Social Compass 66, no. 3 (2019): 418-434

18 Michael Taussig, Shamanism, Colonialism and the Wild Man: A Study in Terror and Healing (Chicago and London: The University of Chicago Press, 1987).

19 Taussig, Shamanism, 134.

20 Taussig, Shamanism, 168.

21 Taussig, Shamanism, 215.

22 Taussig, Mimesis and Alterity, 70.

23 Sharon W. Tiffany and Kathleen J. Adams, The Wild Woman: An Inquiry into the Anthropology of an Idea (Cambridge, Massachusetts: Schenkman Publishing, 1985); Marion Bowman, "The Noble Savage and the Global Village: Cultural Evolution in New Age and Neopagan Thought," Journal of Contemporary Religion 10, no. 2 (1995).

${ }^{24}$ For a discussion of workshops focused on the theme of sexuality, see Carine Plancke, "Yoni Touch and Talk: Sacralising the Female Sex through Tantra," Sexualities (2019), DOI: org/10.1177/1363460719861832.

25 For Belgium and the Netherlands. The Dutch translation of Estes' book means "The Untameable Woman."

${ }^{26}$ For the United Kingdom, in line with the original title of Estes' book. 


\section{Nova Religio}

27 Georgiana Gore, Géraldine Rix, Olivier Wathelet, and Anne Cazemajou, "Eliciting the Tacit. Interviewing to Understand Bodily Experience," in The Interview: Ethnographic Approaches, ed. Jonathan Skinner, pp. 127-42 (Oxford: Berghahn Books, 2013).

${ }^{28}$ For instance, in a wild woman workshop in the Netherlands I participated in-in addition to breathing exercises, bioenergetics work, and some dancingthe main activity involved a sweat lodge modeled on American Indian traditions and conceived of as the womb of Mother Nature. We were invited "to give to her our stuck emotions and patterns" and "to rejuvenate with the elements" by rubbing ourselves with the earth of the lodge. In a final exercise meant to further induce transformation, we were invited to go successively in small groups to a nearby pool to leave behind what we deemed necessary, to the garden in order to ask the help of the nature spirits, and to an adjoining lake where we could make a representation of our yoni (Sanskrit for female genitalia) with natural materials as an expression of our sacred femininity.

29 Specifically, it was a statue of the goddess Pārvatī. However, this was not mentioned in the workshop and I did not hear anyone asking about it. The statue was rather used as a symbol for a generic goddess.

30 Interviews with An and Nathalie, Belgium, 2 August 2016 and 21 February 2017.

${ }^{31}$ No names were given to these goddesses. It was simply seen as a way of acknowledging the presence of the goddess in all of nature.

32 The lack of an air group was a practical issue, since no tasks corresponded to this element.

33 The concept of kundalini, borrowed from yogic practice, refers to an energy that lies at the bottom of the spine and can rise up like a snake along the different energy centers, called chakras.

${ }^{34} 5$ Rhythms is a dance practice that consists of free dancing to five successive rhythms: flowing, staccato, chaos, lyrical, and stillness.

35 This refers to a Tantric meditation An had learned during her training in the Netherlands, but which she re-interpreted for this workshop.

${ }^{36}$ Interview with Elke (pseudonym), Belgium, 1 August 2015.

37 Experienced here as a generic goddess.

38 Interview with Indra (pseudonym), Belgium, 16 July 2015.

39 Interview with Antoinette (pseudonym), Belgium, 14 July 2015.

${ }^{40}$ Interview with Veerle (pseudonym), Belgium, 2 September 2015.

41 Interview with Ine (pseudonym), Belgium, 8 April 2016.

${ }^{42}$ Interview with Marleen (pseudonym), Belgium, 3 September 2015.

43 For more info on Red Tent Gatherings, see Chia Longman, "Women's Circles and the Rise of the New Feminine: Reclaiming Sisterhood, Spirituality, and Wellbeing," Religions 9 (2018): 9.

${ }^{4}$ Starhawk, Spiral Dance: A Rebirth of the Ancient Religion of the Great Goddess [New York: Harper Collins, 1999 (1979)].

45 Starhawk, Spiral Dance, 6.

${ }^{46}$ Starhawk, Spiral Dance, 104. 
47 He also studied with Kalu Rinpoche and received Mahāmudrā transmission. He was also ordained in Sōtō Zen tradition in 2002. He was recognized as a Chan master in 2004 in the Zhao Zhou lineage. "Daniel Odier," Tantra Touch, http:/ / tantratouch.nl/daniel-odier/, accessed 18 June 2018.

48 According to Catherine Wessinger, Kashmir Shaivism can be attractive to contemporary American women because its philosophy deemphasizes the supremacy of male divinity by postulating the equality "of the female on the divine level as well as the human." Thus, the philosophy of Kashmir Shaivism in combination with modern gender expectations can promote a view that affirms the equality of women. See Catherine Wessinger, "Woman Guru, Woman Roshi: The Legitimation of Female Religious Leadership in Hindu and Buddhist Groups in America," in Women's Leadership in Marginal Religions: Explorations Outside the Mainstream, ed. Catherine Wessinger (Urbana: University of Illinois Press, 1993), 125-146, quote on 128.

49 Daniel Odier, L'initiation d'un Occidental à l'amour absolu (Paris: Jean-Caude Lattès, 1996), 11; Daniel Odier, The Tantric Path of Awakening (Vermont: Inner Traditions, 2001), 11.

50 Odier, Tantra, 226.

51 Odier, Desire, 25.

52 Odier, Tantra, 83.

53 Goddess spirituality acknowledges only four elements-earth, water, fire and air-while tantric traditions recognize ether as fifth element.

54 Taussig, Mimesis and Alterity, 61.

55 Taussig, Mimesis and Alterity, 46.

56 Taussig, Mimesis and Alterity, 21.

57 Taussig, Mimesis and Alterity, 16.

58 Taussig, Mimesis and Alterity, 57.

59 Taussig, Mimesis and Alterity, 40.

${ }^{60}$ Interview with Ine (pseudonym), Belgium, 8 April 2016.

${ }^{61}$ Reference is made here to prehistoric feminine statues generally known as "Venus figurines."

62 Ayla is the main character in Jean M. Auel's Earth's Children, a series of novels set in prehistoric Europe.

63 Tessa Bartholomeusz, "Spiritual Wealth and Neo-Orientalism," Journal of Ecumenical Studies 35, no. 1 (1998), 20.

64 Hugh Urban, "The Extreme Orient: The Construction of 'Tantrism' as a Category in the Orientalist Imagination," Religion 29 (1999), 123-146; Hugh Urban, "The Cult of Ecstasy: Tantrism, the New Age, and the Spiritual Logic of Late Capitalism," History of Religions 39, no.3 (2000): 268-304.

65 Suzanne Owen, The Appropriation of Native American Spirituality (New York: Continuum, 2008).

66 Cynthia R. Kasee, "Identity, Recovery and Religious Imperialism: Native American Women and the New Age," Women and Therapy 16, no. 2-3 (1995): 83-93. 67 Deborah Root, Cannibal Culture. Art, Appropriation and the Commodification of Desire (Oxford: Westview Press, 1996). 


\section{Nova Religio}

68 Owen, The Appropriation, 88; Lisa Aldred, "Plastic Shamans and Astroturf Sun Dances: New Age Commercialization of Native American Spirituality," The American Indian Quarterly 24, no. 3 (2000).

${ }^{69}$ Aldred, Plastic Shamans, 330.

${ }^{70}$ Laura Donaldson, "On Medicine Women and White Shame-Ans: New Age Native Americanism and Commodity Fetishism as Pop Culture Feminism," Signs 24, no. 3 (1999): 691, 693.

71 Donaldson, On Medicine Women, 691.

72 Karlyn Crowley, Feminism's New Age: Gender, Appropriation and the Afterlife of Essentialism (New York: Suny Press, 2011), 10.

73 Taussig, Mimesis and Alterity, xiv.

${ }^{74}$ Like the notion of mimesis, the concept of bricolage was also first used with regard to colonized people, notably in the works of Claude Lévi-Strauss and Roger Bastide. See Claude Lévi-Strauss, The Savage Mind, translated by George Weidenfeld and Nicolson [London, 1966 (1962)]. See also Roger Bastide, 1970, "Mémoire collective et sociologie du bricolage [Collective Memory and Sociology of Bricolage]," L'année sociologique 21: 65-108. Bastide, like Taussig, analyzes how it can be a means of resistance against colonial oppression. Only later did it become used for Western spiritual practices and focused hence on individual creativity. See Véronique Altglas, "Bricolage': Reclaiming a Conceptual Tool," Culture and Religion 15, no. 4 (2014): 474-493. I propose a similar move here for the concept of mimesis.

75 Crowley, Feminism's New Age.

${ }^{76}$ Longman, Women's Circles.

77 Longman, Women's Circles, 9.

78 Longman, Women's Circles, 10. 